\title{
Isolation and identification of potential high risk pathogens from blenders used in grinding some food stuffs in a local community market in rivers state: a public health concern
}

\begin{abstract}
Blenders used in cutting and grinding food substances are often times not cleaned up after use. This leads to the proliferation of microorganisms, as these food substances contain nutrients that encourage microbial growth. Samples were obtained randomly in the market by scrapping blenders that had been used to blend Okazi (Gnetum africanum), Ogbono (Irvingia gabonensis), Egusi (Citrullus lanatus) and Crayfish (Procambrous clarkia) in a major local market in Elele Community in Ikwerre Local Government Area of Rivers State. The samples collected were subjected to bacteriological analysis for the isolation and identification of pathogens in food substances. However, results from this study showed that samples from the blender used in blending Ogbono had the highest bacterial colony forming units $\left(1.67 \times 10^{6}\right)$ and the least bacterial colony forming units was from that of the crayfish $\left(2.72 \times 10^{4}\right)$. However, out of the ten bacterial isolates identified, Staphylococcus aureus had the highest frequency of $24 \%$ while Xanthomonas sp. and Pseudomonas sp. had the least frequency of $4 \%$ each respectively. The presence of these pathogenic bacteria poses a huge threat of toxins(s) production and associated diseases and thus should provoke a massive public health concern among stakeholders. Nonetheless, cleaning of blenders before and after use should therefore be encouraged among the market local foodstuff traders, even as the importance of health education and awareness on personal hygiene and food safety should be strongly underpinned in our local communities, so as to reduce the increasing trend of possible food borne epidemic of unimaginable proportion among the weak and most vulnerable subjects in the hinterlands.
\end{abstract}

Keywords: blenders, Okazi, Ogbono, Egusi, Crayfish, pathogenic bacterial, hygiene, community market, health protection
Volume 7 Issue 4 - 2019

\author{
Obioma Azuonwu,' Testimonies Chikanka \\ Azuonwu, ${ }^{2}$ Marcus Azubuike Ndah' \\ 'Department of Medical Laboratory Science, Faculty of Science, \\ Rivers State University, Nigeria \\ ${ }^{2}$ Department of Microbiology, Faculty of Science, Rivers State \\ University, Port Harcourt
}

\section{Correspondence: : Azuonwu O, Department of Medical} Laboratory Science, Rivers State University, Port Harcourt, Nigeria, Tel +2348035519688, Email bimajacobs@yahoo.co.uk

Received: May 25, 2019 | Published: July 02, 2019

\section{Introduction}

Markets are places where buying and selling of products takes place. In most markets found in developing countries, especially in the rural areas, it is probably believed that sanitation of the environment and the cleaning of the drainages are rarely carried out to discourage an outbreak of foodborne epidemics. The traders are probably concerned chiefly on how fast they could finish their products and maximize their profit than paying attention to environmental sanitation details. However, preliminary observatory investigation through weeks of daily monitoring of the level of hygiene outcome in the market by the researchers, revealed that cups used in the measurement of products such as rice, beans, melon and other seed-like products are not cleaned before and after use overtime, thus this would likely promote the presence and proliferation of microorganisms in these cups and measuring buckets, and subsequent transfer same to the products being measured. When these seed products are taken to be ground, the person concerned with this also, does not take out time to clean his machine before and after use, thus providing another good environment for the growth and possible colonization of new microorganisms different from those found in the seeds. Nonetheless, blenders are thus, machines (either electrically or manually operated) used to cut or crush substances (especially food and fruits) into smaller pieces. After blending, there are usually residues of the substance that are left on the blender machine. In most rural communities and markets, after blending, the researchers observed that the blenders are not washed. But are used over and over again, which often provides conducive media for the growth of microorganisms, possibly pathogenic ones to thrive. Nonetheless, such an unprofessional practice remains a massive promoter of an outbreak of foodborne epidemic, such as gastroenteritis and other seeming stomach disorders among unsuspected subjects, especially in rural settings, where access to the functional health system and availability of drugs has been a massive problem begging for attention over the years. ${ }^{1}$

Nevertheless, Irvingia gabonensis (African bush mango seed) popularly called Ogbono in Nigeria is a fruit that has a fleshy part and a nut which has a hard shell and the seed or kernel. The seeds have a hull (outer brown testa) and two white cotyledons. In Nigeria, the seeds are sun-dried, ground into powder and used as soup thickener. ${ }^{2}$ It is the food gum component of these seeds that acts as a thickening agent mainly in hot water. ${ }^{3}$ In the Bwenba Community of Uganda, the white cotyledons are roasted and eaten; the roasted seeds give aroma and flavor to foods especially vegetables. ${ }^{4}$ Proximate analysis of its seeds has shown that they contain $14.1 \%$ carbohydrate, $8.65 \%$ protein, $2.1 \%$ moisture, $1.4 \%$ crude fibre, $16.8 \%$ ash and $38.9 \%$ dietary fibre. ${ }^{5}$ Solvent extraction of the seeds yielded a fat content of $68 \%$ to $75 \%{ }^{5}$

Citrullus lanatus (egusi melon) is the biological ancestor of watermelons but compared with the later whose flesh is red and sweet, egusi melon's juicy flesh is green or pale yellow and is bitter. ${ }^{6}$ Egusi seeds contain vitamin B2 and C, fat, carbohydrate, riboflavin, 
minerals, ${ }^{7} 50 \%$ oil and $35 \%$ protein. ${ }^{8}$ In Nigeria, these seeds are fermented and consumed as "ogiri" $)$. In Abia State (Nigeria), they are ground and eaten with Pleurotus tuber-regium (a mushroom) as a substitute for meat. ${ }^{10}$ They are also used in preparing soups acting as a thickener especially in southern part of Nigeria.

Crayfish (Procambrous clarkia) is a fresh water crustacean resembling small lobsters. They can be eaten dried or boiled. They contain about $10.33 \%$ moisture, $3.83 \%$ crude lipid, $1.3 \%$ crude fibre, rich in protein ${ }^{11}$ but low in carbohydrate. Furthermore, okazi is the Igbo name for Gnetum africanum; in Efik of Nigeria, it is referred to as Afang. It grows as a wild evergreen plant in the rain forest region of Nigeria where it is highly sort in the markets in this region. ${ }^{12}$ This green, hard leaf vegetable is used in preparing delicacies not just in Nigeria but also in Cameroun, Congo, Angola, Gabon and some other African countries ${ }^{13}$ ). In Nigeria, it is used in making soups when prepared together with waterleaves, ogbono or even egusi (melon seeds). These leaves have been found to be useful in the treatment of sore throats, enlarged spleen, reduction of pain during child birth and therapy for some forms of poison and snake bites. ${ }^{14}$

Studies have shown that these products are nutritious and as such can provide a good environment for microbial growth as leaving their residues in these blenders can lead to the proliferation of different microorganisms. This study was thus, aimed at isolating and identifying bacteria found on market blenders that have been used to blend dried crayfish, ogbono, egusi and okazi respectively. Also attempt would be made to highlight the Public Health implications of the association of these microorganisms on our food items especially in the rural areas where access to health facilities and timely health education awareness campaign remains a very huge challenge. ${ }^{15}$ It is thus, strongly believed that data generated from this community based research would strongly underpin the need for the policy makers and relevant health agencies, to drive personal hygiene and health education workshop to our villages, so as to promote the gains of food safety and personal hygiene among rural dwellers. Nevertheless, it is also firmly believed once more, that such an evidence based community study would also stimulate the provision of health facilities that are functional and close to the people, so as to contain with the possible food borne outbreak that could arose, from our communities with already visible lack of health care infrastructure and on hand trained health care expert at the moment, to take care of outbreak of food poison emergency outcomes.

\section{Methodology and study design}

\section{Study area}

This study was carried out in Elele market, located in Elele in Ikwerre Local Government Area of Rivers State. The main occupation of inhabitants are farming, fishing and trading. The market is the major and most critical market in the area, and as such, attract large amount of buyers and sellers visiting the market during the market day, which is often scheduled for the $7^{\text {th }}$ day of every week in the area

\section{Sample collection/research design}

The location in the market that harbors the ground machines were conveniently divided into four zones, this is to make sure that a representative sample was collected evenly, among the grinding machines in the market. The samples were collected randomly among the four divided zones by aseptically scrapping the market blenders that have been used to ground selected food samples, and were aseptically delivered into sterile containers. It was transported to the laboratory of Department of Medical Laboratory Science, Rivers State University immediately in cold chain, for bacteriological studies/ analysis as described by Cheesbrough. ${ }^{16}$

\section{Microbiological analysis}

One gram $(1 \mathrm{~g})$ of each samples was added to $9 \mathrm{ml}$ of normal saline from which a 10-fold serial dilution was carried out and 0.1 $\mathrm{ml}$ from dilution $\left(10^{-1}\right.$ to $\left.10^{-5}\right)$ of each sample was plated on freshly prepared Nutrient agar plates in duplicates; these were incubated in a well regulated incubator for 24 hours at $37^{\circ} \mathrm{C}$ for the isolation of bacteria pathogens. ${ }^{16}$ Pure cultures were obtained by sub-culturing distinct colonies on freshly prepared culture plates. Identification of bacterial isolates was carried out using Gram's stain reaction, motility, indole, spore formation, sugar fermentation tests, starch hydrolysis and catalase, MR-VP, coagulase and oxidase tests. Pure cultures that had been identified were stored on Nutrient Agar slants as described in Cheesbrough. ${ }^{16}$ Multiple antibiotic tests were carried out by preparing the cultures according to MacFarland's standard. Using sterile swabs, the cultures were streaked on Mueller Hinton agar, a ring containing 8 antibiotics (Gentamicin, Ofloxacin, Augmentin, Ceftazidime, Cefuroxime, Nitrofurantoin, Cefixime and Ciprofloxacin) was placed on each plate and the plates incubated at $37^{\circ} \mathrm{C}$ for 24 hours.

\section{Results}

Randomly selected blenders that had been used to ground egusi, ogbono, okazi and crayfish (local food stuffs) in a major local Elele market were scrapped and inoculated on Nutrient agar (bacteria medium) aseptically. The bacteriological analysis results revealed that the blender used to ground ogbono had the highest bacterial count of $1.67 \times 10^{6}$ compared with that of egusi $\left(2.80 \times 10^{4}\right)$, okazi $\left(1.62 \times 10^{6}\right)$ and crayfish $\left(2.72 \times 10^{4}\right)$ as shown in Table 1. Regardless of the high dilution factor $\left(10^{3}\right)$ used, the microbial load in the blenders used to ground okazi and ogbono was still high. Of the ten isolates, Staphylococcus aureus had the highest frequency with a percentage occurrence of 24 as shown in Table 2. Xanthomonas sp. and Pseudomonas sp. had the lowest frequency of $4 \%$ each. On all four blenders, there was the occurrence of Staphylococcus aureus while Escherichia coli and Klebsiella sp. occurred only in the blender used for egusi. Bacillus sp. occurred in the egusi, crayfish and ogbono blenders. Micrococcus sp. and Pedicoccus sp. occurred in the blenders used for okazi and egusi. Lactobacillus sp. occurred only in the blenders used for egusi and crayfish. Figure 3 shows a plate were multiple antibiotic sensitivity test for Klebsiella $\mathrm{sp}$. was carried out. Figure 4 shows the percentage sensitivity of the isolates to the antibiotics with a good percentage exhibiting resistance to Augmentin and $100 \%$ being susceptible to Ofloxacin (Figures $1 \& 2$ ).

Table I Bacterial load count of grinded food samples

\begin{tabular}{llll}
\hline Sample & Dilution & No. of colonies & Viable count (cfu/g) \\
\hline Egusi & $10^{-1}$ & 282 & $2.80 \times 10^{4}$ \\
Okazi & $10^{-3}$ & 162 & $1.62 \times 10^{6}$ \\
Ogbono & $10^{-3}$ & 162 & $1.67 \times 10^{6}$ \\
Crayfish & $10^{-1}$ & 272 & $2.72 \times 10^{4}$ \\
\hline
\end{tabular}


Table 2 Frequency of isolated bacteria according food stuffs examined

\begin{tabular}{llllll}
\hline Isolated organism & Frequency & Okazi & Egusi & Crayfish & Ogbono \\
\hline Staphylococcus aureus & $12(24 \%)$ & + & + & + & + \\
Escherichia coli & $4(8 \%)$ & - & + & - & - \\
Bacillus sp.. & $8(16 \%)$ & - & + & + & + \\
Klebsiella sp.. & $4(8 \%)$ & - & + & - & - \\
Lactobacillus sp.. & $7(14 \%)$ & - & + & + & - \\
Pseudomonas sp.. & $2(4 \%)$ & - & + & - & - \\
Micrococcus sp.. & $4(8 \%)$ & + & + & - & - \\
Xanthomonas sp.. & $2(4 \%)$ & + & - & - \\
Pedicoccus sp.. & $4(8 \%)$ & + & + & - \\
Unidentified & $3(6 \%)$ & + & - & + \\
Total & $50(100 \%)$ & & & - \\
\hline
\end{tabular}

Key: -, absent; +, present

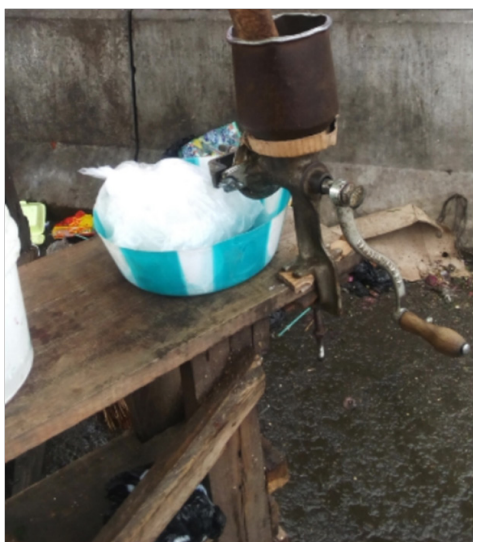

Figure I A picture of food stuff ground machine taking in the local market study environment.

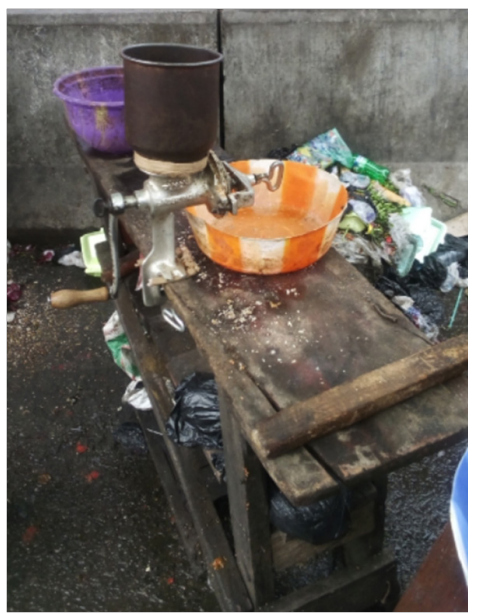

Figure $2 \mathrm{~A}$ picture of ground machine used in blending local food stuffs in the study local market.

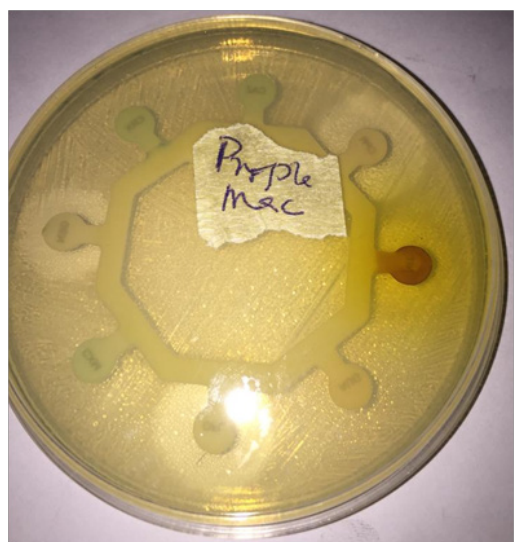

Figure 3 Plate showing multiple antibiotic sensitivity test for Klebsiella sp.

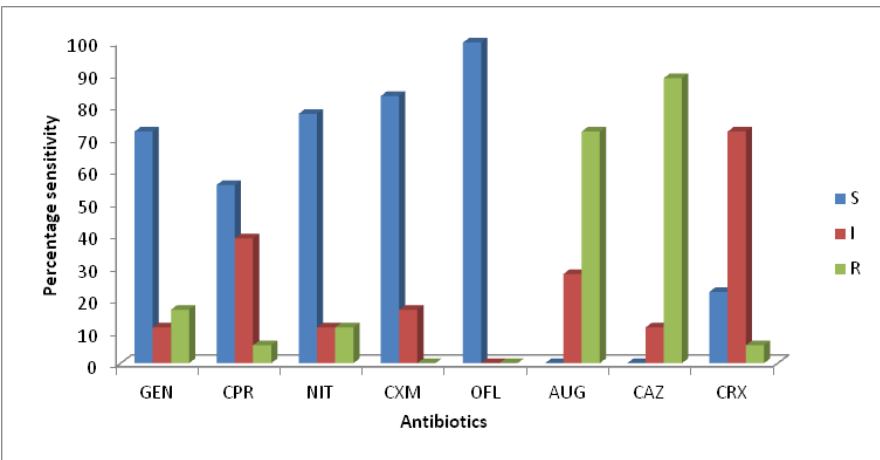

Figure 4 Key: S, sensitive; I, Intermediate; R, Resistant; GEN, Gentamicin

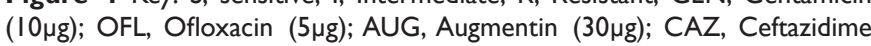

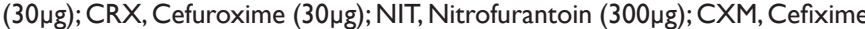
$(5 \mu \mathrm{g})$ and CPR, Ciprofloxacin $(5 \mu \mathrm{g})$. 


\section{Discussion}

Blenders used in cutting food substances into smaller pieces are important, but the occurrence of microorganisms in the ones that have been used and re-used before being cleaned (if at all they are cleaned) is of public health importance. In the market, probably due to the large number of persons coming to blend food stuffs, the persons doing the blending end up re-using the blenders without proper cleaning not minding the source of the food stuff. Sometimes, the food stuff may be already or almost spoilt (as in the case of some fresh pepper and tomato brought for blending), thus depositing some food spoilage microorganisms on the blender. Without proper cleaning, these organisms may replicate sporadically and be transferred to the new food stuff brought for blending also.

Bacterial isolates were obtained from the samples. The origin of these microorganisms may have been from the food samples that were blended or better still, from the water used in cleaning the blender before use, or even from the environment such as the dust from the soil. Since the market is a busy one, particulate matter carrying microorganisms may have been deposited on the blenders. On the other hand, sometimes water used in cleaning the blenders may have been stored for a long period of time, and probably some pathogenic microorganisms may have proliferated in the water. Also, sometimes, food brought for blending may be spoilt already and so the bacteria from these decayed food samples may be deposited on the blender during the process. These scenario tend to put the unsuspecting public at massive potential risk with strong public health concern of food poisoning outcome, if not checked in good time to nip it at the board.

However, the isolation of Bacillus sp. from the blender that had been used to ground ogbono was in agreement with the study by Ekundayo et al., ${ }^{17}$ who isolated these organisms and some other pathogens from fermented ogbono seeds. The presence of Staphylococcus aureus and Bacillus sp. is a potential risk as these organisms are able to produce toxins which are harmful to humans when ingested. ${ }^{18}$ Bacillus $s p$. is normally found in the soil and may have been of vegetable origin. The consumption of these organisms in large numbers, probably above $100 \mathrm{cfu} / \mathrm{ml}$ could probably lead to gastrointestinal illness, though the degree and critical nature of the infection in an individual may differ, based on individual specific immune response capacity and integrity. It is strongly believed that those who are immune compromised, possibly who are on steroid drugs and those who are suffering from terminal diseases are likely to be affected massively. Nonetheless, others who might be at risk also are the infants and the aged with weak immune competence. However, toxins of Staphylococcus aureus on the other hand when found in food samples and consumed can cause diarrhoea, vomiting and stomach cramps. These are pathogenic cum food poisoning microorganisms, as such, should not be found in our food stuffs or instruments used in preparing and processing food, if the health of general public must be protected at all time.

The occurrence of $S$. aureus which are Gram positive cocci, catalase-positive, coagulase-positive, oxidase-negative and facultative anaerobes in all samples strongly suggests a high level of personal hygiene compromise in association with the usage of these blenders. Although $S$. aureus is often associated with the skin and mucous glands (especially in the nose of healthy persons) as commensals, ${ }^{19}$ it is also pathogenic at some point. It has been implicated as one of the main causes of community and hospital-acquired infections which may lead to serious public health consequences. ${ }^{20}$ Hospitalacquired infections also known as nosocomial infections resulting from $S$. aureus affects the lower respiratory tracts, bloodstream, skin and soft tissues as it can cause osteomyelitis and endocarditis among other infection..$^{21}$ Toxins produced by $S$. aureus have been associated with toxic shock syndrome (TSS), staphylococcal foodborne diseases (SFD) and scalded skin syndrome. ${ }^{22}$ Nevertheless, Bacillus species is also a Gram-positive facultative anaerobe; it is catalase-positive, motile and endospore-forming microorganism..$^{23}$ They are able to form heat-resistant spores in the soil as their natural habitat; hence the contamination of food, with sand or dust blown up by air current may probably be one of the ways of introducing pathogens on the food stuffs. Nonetheless, the researchers also firmly believed that, their ability to form these spores is a major reason for their huge virulence and persistent pathogenicity in an infected host.

The presence of Klebsiella species and Pseudomonas species in these samples suggest that, if the blender is used to blend another food item and it is either not cooked or not properly cooked before consumption, gastroenteritis may result as these microorganisms are often associated with gastrointestinal infections. It is therefore, very imperative that these microorganisms be eliminated from food samples, and material used in food preparation to prevent bacterial infections. Although antibiotics have been widely used to treat infections that are associated with these microorganisms, in the rural areas where there is little or no access to quality health care delivery, if one comes down with an illness, resulting from infection by these microorganisms, the result will either be that antibiotics will be abused leading to antibiotics drug resistance or the patient morbidity and mortality rate may increase geometrically. Therefore, it is of utmost importance that the food sample must not be a decayed one and the spread of dust within the environment where the blending is done, should be reduced as much as possible, so as to reduce contamination of the items. The resistance of the bacterial isolates to Augmentin is of public health concern, even as it is often used as a drug of choice in the treatment of bacterial infections. However, in place of it, Ofloxacin may be used for the treatment of such infections, but what is of massive worry for now is the scenario where the use of Augmentin which is a broad spectrum antibiotic has been abused in the local communities with a resistance feedback, then what next, in a changing world of antibiotic and multiple drug resistance history, even when living in the villages may not be financially strong to go for other alternative antibiotics with strong and broad spectrum capacity.

However, the importance of the provision of potable water in all the nook and cranny of our local markets by government and her agencies cannot be over emphasized, It is probably believed that nonprovision of potable sources of water, which should be accessible regularly for washing and keeping the environment clean may likely promote these public health issues in our local markets, thus the public health implication of such practice is very massive, as cases of gastroenteritis and diarrhoea will be highly prominent in the area. This is a great public health concern and potential health risk that calls for urgent attention. Nevertheless, it is strongly believed that if these sceneries are not managed in good time, many subjects would be victims of food borne infections, even as the cases of antibiotic resistance saga in our local communities would continue to be on the increasing trend since the infected local populace always seek for medical attention through the practice of self-medication approach or the use of herbal mixtures that lacks accurate measurement of an active ingredients.

\section{Conclusion and recommendation}

Some Gram positive and Gram negative pathogenic microorganisms were isolated from blenders that had been used to blend egusi, ogbono, 
okazi and crayfish, suggesting a public health risk as the blenders are often used and re-used without sanitization. Staphylococcus aureus, Bacillus sp., Xanthomonas sp., Escherichia coli, Pediococcus sp., Pseudomonas sp., Klebsiella sp., Lactobacillus sp. and Micrococcus sp. were among the isolated bacterial species. Although they did not all occur in all the four samples, Staphylococcus aureus had the highest percentage occurrence. An unidentified organism was also isolated and had a percentage occurrence of $6 \%$. The viable counts showed that ogbono had the highest microbial count. Nevertheless, it is strongly suggested that proper cleaning and disinfection of these blenders should be carried out before and after use to ensure that they are free from potential microbial pathogens, which are harmful to humans and possibly animals. Water used in cleaning these blenders must be potable water and should be accessible. The environment where the blenders are kept should be cleaned properly as there is a probability that dirt-carrying microorganisms may be deposited on the blenders or food samples to be ground. Awareness campaigns by public health workers on the dangers of using and re-using blenders without proper cleaning should be carried out from house to house, and even in the markets; not just in the urban areas but in the rural areas too, to encourage the proper cleaning of blenders and ground machines before and after use. Where possible, each household should be encouraged to have its own personal blender to avoid going to the market to blend, where you are not sure of the safety of the blending or ground machine being used for commercial purpose.

Studies on the microbial load of household blenders used in blending different food samples should be carried out so as to ascertain, if the isolated microorganisms were from the food samples or from the environment where the blenders are kept.

\section{Acknowledgments}

We wish to thank all the laboratory staff of River State University where the analysis was done for their kind and promptly support. We are also grateful to Elele market blenders association for granting us access to their members and machines to collect the samples for the analysis. Nevertheless, we are also thankful to Prof S.D Abbey for all his fatherly support and encouragement, even as we will not forget the prayers of Dr Azuonwu, Goodluck, Benneth Azuonwu and Fanny Anokwuru.

\section{Conflicts of interest}

None reported among authors.

\section{References}

1. Azuonwu O, Nnenna I, Douglass AS, et al. Consequences of Haemolytic Disease of the Fetus and Newborn (HDFN) and the Clinical Significance of Antibody Screening in Prenatal Diagnosis: A Study of Multigravidal and Primigravidal Women in Port Harcourt, Niger Delta. Journal of Clinical Laboratory Medicine. 2016;1(1):1-7.

2. Ekpe OO, Umoh IB, Eka OU. Effect of a typical rural processing method on the proximate composition and amino acid profile of bush mango seeds (Irvingia gabonensis). African J Food Agric Nut Dev. 2007;7(1):1-12.

3. Ndjouenkeu R, Goycoolea FM, Morris ER, et al. Okra (hibiscus esculentus) dika nut (Irvingia gabonensis) polysaccharides. Car Polym. 1996;29(3):263-269.

4. Ousseynou N, Nicodeme T. A paper on Utilization and marketing of Irvingia gabonensis produce in the humid forest of Cameroon. International Institute of Tropical Agriculture and the Rockefeller Foundation; 1994. $80 \mathrm{p}$.
5. Okolo HC. Indigenous Manufacturing of selected Nigerian foods in packaged form for defence usage. Paper presented at first Ministry of Defence TRADOC Seminar Benin City; 1987. 20 p.

6. Ojieh G, Oluba O, Ogunlowo Y, et al. Compositional Studies of Citrullus lanatus (Egusi melon) Seed. The Internet Journal of Nutrition and Wellness. 2007;6(1):1-5.

7. Lazos ES. Nutritional, Fatty acid and Oil Characteristics of Pumpkin and Melon Seeds. J Food Sci. 1986;51(5):1382.

8. Jack TJ. Cucurbit Seeds: 1. Characterizations and uses of Oils and Proteins. A Review, Economic Botany. 1972;26(2):135-141.

9. Abiodun OA, Adeleke RO. Comparative Studies on Nutritional Composition of four melon seeds varieties. Pakistan Journal of Nutrition. 2010;9(9):905-908.

10. Nwokolo E, Sim JS. Nutritional assessment of defatted seed meal of melon (Colocynthiscitrullus $L$.) and fluted pumpkin (Telfariaoccidentalis Hook) by chick assay. J Sci Food Agric. 1987;38(3):237-246.

11. Ahmad SN, Birnin-Yauri UA, Bagudo BU, et al. Comparative analysis on the nutritional values of crayfish and some insects. African Journal of Food Science and Technology. 2013;4(1):9-12.

12. Okerulu IO, Onyema CT. Comparative Assessment of Phytochemicals, Proximate and Elemental Composition of Gnetum africanum (Okazi) Leaves. American Journal of Analytical Chemistry. 2015;6(7):604-609.

13. Dutta A. Botany for Degree Students. 5th ed. Oxford University Press: Dellin; 1981. 286-288 p.

14. Mailoundama F. Nutritional and Socio-Economic Value in Central African Forest. In: Itladikom, Eds., Tropical Forest People and Food: Bio-Cultural Interactions and Applications to Development, Parthenon Publishing Group: Carnforth; 1993.

15. Azuonwu O, Nnenna I, Uwuma OE. Evaluation of Hematological Profile of Geriatric Subjects in Port Harcourt Metropolis of Niger Delta of Nigeria. Journal of Clinical Laboratory Medicine. 2017;2(1):1-5.

16. Cheesbrough M. District laboratory Practice in Tropical Countries. Part 2. Cambridge University Press; 2006. 143-157 p.

17. Ekundayo FO, Oladipupo OA, Ekundayo EA. Studies on the effects of microbial fermentation on bush mango (Irvingia gabonensis) seed cotyledons. African Journal of Microbiology Research. 2013;7(34):43634367.

18. Dinges MM, Orwin PM, Schlievert PM. Exotoxins of Staphylococcus aureus. Clin Microbiol Rev. 2000;13(1):16-34.

19. Crossley KB, Archer GL. The Staphylococci in human disease. Churchill Livingstone: New York; 1997.

20. Diekema DJ, Pfaller MA, Schmitz FJ, et al. Survey of infections due to Staphylococcus species: frequency of occurrence and antimicrobial susceptibility of isolates collected in the United States, Canada, Latin America, Europe, the Western Pacific region for the SENTRY Antimicrobial Surveillance Program 1997-1999. Clin Infect Dis. 2001;32(Suppl 2):S114-S132.

21. Schito GC. The importance of the development of antibiotic resistance in Staphylococcus aureus. Clin Microbiol Infect. 2006;12 (Suppl 1):3-8.

22. Plata K, Rosato AE, Węgrzyn G. Staphylococcus aureus as an infectious agent: overview of biochemistry and molecular genetics of its pathogenicity. Acta Biochim Pol. 1976;56(4):597-612.

23. Waites MJ, Morgan NL, Rockey JS, et al. Industrial Microbiology an Introduction. London: Blackwell Publisher; 2008. 